\title{
Nigerian University and Manpower Development in a Changing World
}

\author{
Adam Adem Anyebe ${ }^{1}$ \\ ${ }^{1}$ Department of Public Administration, Faculty of Administration, Ahmadu Bello University, Zaria \\ Correspondence: Adam Adem Anyebe, Department of Public Administration, Faculty of Administration, \\ Ahmadu Bello University, Zaria. E-mail: adamanyebe@gmail.com
}

Received: September 16, 2013 Accepted: December 19, $2013 \quad$ Online Published: January 24, 2014

doi: $10.5539 /$ hes.v4n $1 \mathrm{p} 82$

URL: http://dx.doi.org/10.5539/hes.v4n1p82

\begin{abstract}
This paper examines Nigerian university system in relation to manpower development in a rapidly changing world of work. This is for purposes of identifying areas that need urgent attention in order to reposition the system to produce high quality manpower. The study reveals that the expansion in the university system is characterized by a mixed bag of limited success, and continuing challenges. For Nigerian university to fulfill its objective effectively, the system needs to be systematically planned in order to produce graduates that are versatile enough to acquire competitive positions as well as generate their own employment.
\end{abstract}

Keywords: university, expansion, competitiveness, planning, exponential

\section{Introduction}

Knowledge and skill that emanate from the pursuit of education are utilitarian because they uplift the individual by giving him the comportment, awareness and the desire to serve and thus transform society. Thus, education is a social project whose object is the relationship between man and nature and how the transformation of this can lead to social development. In principle, every society or community aspires towards stability and progress, thus, education is usually treated with considerable respect and interest (Abubakar, 2004). This is to be expected, especially of developing countries that place a high premium on education as a panacea for socio-economic development.

However, the recognition of the utilitarian value of education and the creation of structures and stages for its actualization do not imply that the views on and attitudes towards education as an agent of change and development, are universal, all-embracing and accessible to all. This means that every society's approach to the educational question varies from the perspective of time and place or indeed from the dictates of historical circumstances. Inevitably, the nature, scope and orientation of educational system vary in response to time, perception and interest. Expectedly, the National Policy on Education (2002) directs the focus of Nigerian university towards achieving the following objectives:

development and inculcation of proper value-orientation for the survival of the individual and society; development of the intellectual capacities of the individuals to understand and appreciate their environments; acquisition of both physical and intellectual skills which will enable the individuals to develop into useful members of the community; and the acquisition of an objective view of national and international environments.

In the post-independence era, the development of university education closely followed the evolution of the country from the debris of colonialism, its crisis of underdevelopment and its current transition into corporate, globalised capitalism with its attendant rupture of the general principles of the welfare state. This schema entails a disorderly oscillation between the developmentalist and the entrepreneurial path in the evolution and growth of universities (Abubakar, 2004). In the first place, universities were created to produce manpower for development in an essentially state regulated economy in which government has been an active player. The guiding principle in this project was the training of persons to acquire the requisite knowledge, leadership skill and commitment to national development, integration and liberal humanism.

In direct proportion to this notion of public good, all levels of government-local, state and Centre-built and funded educational institutions to actualize the objectives of university education. Consequently, in 1960, Ashby 
Commission recommended the establishment of the first generation universities in the following sequence:

$>$ The University of Nigeria, Nsukka was established in 1960 by the then Eastern Regional Government as the first Nigerian initiated university;

> The University of Ife, Ile-Ife (now ObafemicAwolowo University) though not recommended by Ashby Commission, was founded in 1961 by the then government of Western Region; and

$>$ The Ahmadu Bello University, Zaria was founded in 1962 by the then Northern Regional Government.

These universities were established in addition to the existing two federal universities then; the University of Ibadan, Ibadan (was a University College from 1948 until the bill making it an autonomous institution was passed in December 1962) and the University of Lagos, Lagos established in 1962. In 1963 when the defunct Mid-Western Region was carved out of the then Western Region, she demanded for a university of her own. However, the Region had to wait till the end of the national crisis in 1970 before getting a university. The University of Benin was finally founded in 1972 as an offshoot of the then Mid-West Institute of Technology.

Another relevant recommendation contained in the Ashby Commission Report was that 7,500 students should be enrolled in Nigerian universities by 1970. Actually, the total enrolment in the universities in 1970/71 session was 15,272 distributed as follows: Ahmadu Bello University, 2,689; University of Nigeria 2,929; University of Ife 2,423; University of Ibadan 3,655; sand University of Lagos 2,536 (Ayo, 1988). This is far more than the Ashby Commission target. Since then there has been the proliferation of universities in the country leading to a tremendous increase in student enrolment. The Third National Development Plan 1975-1980, made provision for the establishment of seven more universities to be located in states where there were none at the time. This gave birth to the second-generation universities in 1975.

Until 1971, university education was on the concurrent legislative list of the Nigerian Constitution, thus allowing the former regions of the federation to establish their own universities. Later, all the universities were taken over by the federal government or were voluntarily handed over to it by their respective states purely for reasons of financial incapacity. That was the case for the University of Nigeria, Nsukka and University of Benin, which were handed over to the federal government in 1971 and 1975 respectively. Also, the federal government took over the former regional universities in Ife and Zaria. This was the situation until 1979 when university education was put on the concurrent list again.

It was projected in the 1981-85 plans that about 108,720 students would be enrolled in the university system by 1985. It was, therefore, stipulated in the plan document that:

In order to meet the increased level of demand for university places the existing universities will be expanded, seven new universities of technology and one unconventional university with emphasis on postgraduate studies will be established to cater for the needs of those who are unable to go to conventional universities (1981-1985 Plan Document).

All the above universities were expected to be established to cater for the projected enrolment of about 108,720 students. National policy on education also in consonance with the projection in the plan wanted the new universities established to ensure even geographical distribution as a means of ensuring national unity. Thus, the universities of technology were sited at Bauchi (in Bauchi State), Makurdi (in Benue State), Yola (in the then Gongola State), Akure (in Ondo State), Owerri (in Imo State), Abeokuta (in Ogun State), and Minna (in Niger State). The National Open University whose bill was passed by the House of Representatives on July 16, 1981, Senate on April 20, 1983 and finally signed into law on July 22, 1983 was sited at Abuja.

One thing that was economically unwise about the establishment of the universities is that, no sooner was the 1981-85 plan launched than the world oil market weakened (oil was and still the main foreign exchange earner of Nigeria). The federal government religiously went ahead to establish the seven universities of technology and the National Open University. As if this lack of economic wisdom on the part of the federal government was not enough, eight state governments took advantage of the fact that the 1979 Constitution put university education on the concurrent legislative list to establish their own universities without adequate appraisal. Thus, we had eight state universities, many of them with satellite campuses.

During this period, a strange phenomenon also began to appear and that was the private sector investing in the establishment of universities. The most famous of these was Imo Technical University founded by one Dr. Ukaegbu. When the legality of starting a private university was challenged in the courts, the Supreme Court finally ruled in 1983 that it was perfectly legal for individuals or private concerns to establish private universities or at least that there was nothing in the Constitution and the laws of the country preventing the establishment of private universities. Within six months of this ruling of the Supreme Court, 26 private universities were either 
established or proposed in the country.

Faced with what could best be described as an avalanche of universities, the Federal Military Government in June 1984 abolished all private universities and prohibited the establishment of new ones in the foreseeable future by Decree No. 19 of 1984 . The government also merged four of the seven federal universities of technology with some conventional universities while the National Open University was stopped in order to restore some sanity to the system.

Most of the universities established during the plan period were politically inspired. This must have led the Military Government in 1984 to issue a policy statement that there was proliferation of universities without regard to the resource capacity of the country (Anyebe, 2009). Probably, as a result of this proliferation a nationwide accreditation of academic programmes (National Minimum Standards and Establishment of Institutions) Decree 16 of 1985 was put in place, amended by Decree 9 of 1993 . This law was to ensure maintenance of minimum educational standards at all levels of educational system in Nigeria. The National Universities Commission (NUC) also issued minimum course outlines to ensure some degree of uniformity in academic standards, while still allowing universities some level of autonomy in curriculum development.

That university education is highly politised in Nigeria should not come as a surprise because of upsurge in the awareness of the general populace about the importance and value of education. Thus, the popular demand for university education grew and the passionate desire of common men and women to give their children a better chance in life gave the social demand for education its explosive quality, and made of it a political force that no democratic government could long resist. Furthermore, in giving recognition to the important contribution of education to political, economic and social changes in society, the National Policy on Education (1981) states that not only is education the greatest force that can be used to bring about redress, it is also the greatest investment that the nation can make for the quick development of its economic, political, sociological and human resources. There are therefore, all the necessary ingredients that should bring about explosion in enrolments in universities in Nigeria.

It is against this backdrop that the researcher poses this research question: What is the quantity and quality Nigerian university education vis-a-viz manpower development?

\section{Research Method}

Some basic historical documents were relied upon for purposes of data collection for this study — journals, books, bulletins of NUC, JAMB, and other agencies of government, unpublished materials as well as internet materials. Personal interviews were held with some NUC, JAMB and university officials. The interviews were intended to extract from the managers of the university system their reflections on the system with which they were actively involved. 4 officials, comprising 1 vice-chancellor, 1 director each from NUC and JAMB and 1 official from ASUU were selected for interview.

Each interview lasted between 20 to 30 minutes and it took the form of discussion organized around the following issues: expansion, quality, funding, leadership, union activities and employment. All interviews were preceded by formal requests and the issues were raised in the e-mail and text messages. Replies were received indicating willingness to grant the interview and the scheduled time. Notes were taken down and the relevant jottings were read to the hearing of the interviewees for their consent. The secondary data were analysed using tables and simple percentages.

\section{Results and Discussion}

\subsection{Expansion}

Student enrolment in Nigerian universities has increased exponentially in the last two decades. This has resulted from the insatiable demand for university education in the country. The country's answer to this social demand for higher education was to increase student enrolment by opening more universities.

Let us take the enrolment figures in table 1 to illustrate the expansion in the enrolment between 1996 and 2000 . 
Table 1. Admission statistics in Nigerian universities (1996-2000)

\begin{tabular}{lccc}
\hline Year & Number of applicants & No. of candidate admitted & Percentage of candidates admitted \\
\hline 1996 & 376,645 & 56,055 & 14.9 \\
1997 & 419,809 & 73,381 & 17.6 \\
1998 & 321,368 & 78,550 & 24.4 \\
1999 & 593,670 & 64,358 & 10.8 \\
2000 & 467,490 & 50,277 & 10.8 \\
\hline
\end{tabular}

Source: Extracted from Annual Report of JAMB, 1996-2000.

For the five years examined in table 1, it is evident that the enrolment varied from year to year: 56, 055 in 1996; 73, 381 in 1997; 78, 550 in 1998; 64, 358 in 1999; and down to 50, 277 in 2000, with the highest and the lowest enrolments in 1998 and 2000 respectively. Even with this explosion in enrolment, there was no year the universities admitted up to $25 \%$ of the applicants. The high number of applicants is a demonstration of the insatiable demand for university education in the country.

The following admission statistics in table 2 demonstrate the exponential increase in student enrolment from 2002-2007

Table 2. Admission statistics in Nigerian universities (2002-2007)

\begin{tabular}{crrc}
\hline Academic session & Application statistics & Admission statistics & Percentage of candidates admitted \\
\hline $2007 / 2008$ & 911,653 & 107,370 & 12 \\
$2006 / 2007$ & 803,472 & 88,524 & 11 \\
$2005 / 2006$ & 916,371 & 76,984 & 8.4 \\
$2004 / 2005$ & 841,878 & 122,492 & 15 \\
$2003 / 2004$ & $1,046,950$ & 105,157 & 10 \\
$2002 / 2003$ & 994,380 & 51,845 & 5.2 \\
\hline
\end{tabular}

Source: see http://www.jambng.com/app_ume.php

Table 2 reveals the exponential increase in admission into Nigerian universities between 2002 and 2007, where data were available. The highest enrolment was in 2004/2005 session why the lowest was in 2002/2003 session. Even then, there was no session the universities were able to admit up to $16 \%$ of the applicants, demonstrating again the explosive social demand for university education.

Today, according to NUC sources there are 127 universities including one national Open University in Nigeria. The establishment of new universities suddenly became the most popular solution to the problem of coping with the teeming thousands who were desirous of having university education. We are told not to relate the proliferation of universities in Nigeria to political expediency but to relate these developments to the genuine desire to absorb qualified candidates who are thirsty for university education. Establishing more universities may solve one aspect of the problem. There is always the tendency to think solely in terms of opening more universities without giving sufficient attention to the function and role that universities are expected to play in relation to country's needs. Coombs (1969) asserts that the number of candidates wanting to enter institutions of higher learning reflects society's demand for education; but whether what the students want to study is the same as manpower requirements for economic and social development is another matter entirely. The two may interact, yet behave quite independently. Social demand for education has a way of growing faster than manpower requirements, leading, on some occasions, to "unemployment of the educated". In the country's attempt to cope with the growing numbers wanting university education, the country must not be stampeded into taking actions that would only help in compounding the very problems it is supposed to solve. Nigerian university system does not appear to be integrated with the economic system of the country, rather the system has developed on its own producing more of the same from the number of universities that there are. We do not seem to have the knowledge or the strategy to harness the knowledge acquired by the products of the system to promote societal 
needs. This is not too surprising. The needs of the society were not taken into account when fashioning the curriculum contents of the educational programmes at the university level. This finding was supported generally by an informant (a director at JAMB) who said that though public policy in the last decade or so has promoted a rapid quantitative growth of universities, this has not correspondingly translated into expansion of access. To worsen the situation many of the graduates are unemployable because their skills do not usually match the requirements of available jobs.

The choice of courses studied by students in Nigerian universities provides interesting reading for their diversity. In Ahmadu Bello University, the sample of subjects of choice by direct entry students in 2007/2008 session shows the following profile:

Table 3. Choice of course in Ahmadu Bello University, 2007/2008

\begin{tabular}{lc}
\hline Course & No. of students who chose the course \\
\hline Administration & 182 \\
Agriculture & 29 \\
Arts & 241 \\
Education & 544 \\
Engineering & 60 \\
Environmental Design & 30 \\
Law & 48 \\
Medicine (MBBS) & 27 \\
Pharmaceutical Sciences & 20 \\
Science & 99 \\
Social Sciences & 117 \\
Veterinary Medicine & 1 \\
\hline
\end{tabular}

Source: Ahmadu Bello University, Zaria, 2007/2008 Matriculation List

According to table 3, education (544) tops the list of most preferred course with Arts far second (241). Are the major choices reflective of the needs of the society and or national development? The sciences are way down the ladder and that does not augur well for the scientific development of Nigeria. Courses like pharmaceutical sciences and veterinary medicine had only twenty candidates and one candidate respectively, admitted. The example of this university is not an isolated case; a detail study and analysis of the choice pattern of the Nigerian students for their university education will reveal a great deal about the trend of the thinking of the youths of this country.

\subsection{Quality}

One inevitable price a nation may pay for unprecedented explosion in student enrolment at the university level, especially if this explosion is not accompanied by a corresponding improvement in facilities, quality of teachers, teaching materials etc., is dilution of quality of graduates. The explosion may adversely affect the quality of the graduates if the university system is not prepared to cope with the situation.

Beeby (1968) discusses three levels at which the quality of education may be assessed. He referred to the first level as the "classroom conception of quality". This is the stage at which skills and a given range of facts can be measured; the second stage is where the quality of education is measured by its productivity. The third and final level is the stage at which quality is assessed by broader social criteria. The quality of education in Nigeria should be measured by achievements at each of the three levels identified above. The first level has to do with the quality of instruction obtainable in the system; the second deals more with the relevance of the education to developmental needs and the third deals more with the philosophical basis of education.

But of immediate importance to Nigeria is to assess the extent to which it is prepared to minimally attain a certain degree of quality using Beeby's first level criteria, that is, the quality of instruction obtainable within the system, as the guideline. In isolating the quality of instruction for close study, cognizance must be taken of the 
fact that while relevance and philosophy are equally important, the absence of properly oriented lecturers may have a more telling effect on the attainment of desired educational goals at all levels of the country's educational endeavour. There is no doubt that the idea of excellence in any school (college or university) depends on the goals it sets itself, but that these goals are in turn dependent on what the teachers in the school are capable of doing. There is no question that the quality of the academic programme of a university is dictated by the quality of the staff therein. Furthermore, according to Baikie (2002) the re-orientation taking place in our concept of higher education demands that: the staff must not only be adequate in numbers and fully qualified in the formal traditional sense, they must also be fundamentally oriented to their environment and dedicated to promoting the University not merely as an institution of higher learning but as one of total commitment to the community at large. After decades of near total dependence on overseas universities for staff training and development, it is gratifying to note that Nigerian universities, at least the older ones, are making a headway in the establishment of graduate schools where staff could be trained locally.

Of relevance to the quality of education received at the university level is the equally relevant issue of the quality of staff in universities. One can attest to the fact that the quality of staff in nearly all Nigerian universities was good and could stand any test anywhere. However, there is the grave danger of losing this quality if employment practices that appear to be gaining ground in the system are allowed to continue without some caution (Baikie, 2002). Particular reference is here being made to appointments at high academic level (associate professor and professor). In the attempt to develop degree programmes, we find that candidates, who were found not appointable as associate professors or professors in one university, could easily be appointed to the same professorial posts elsewhere in the country without as much as passing through the rigours of assessment. No one would begrudge an individual the opportunity of a higher appointment, but we must guard against watering down the system to a ridiculous level.

\subsection{Funding}

One of the intractable problems facing Nigerian universities today is the issue of funding. Initially, the funding was fairly adequate mainly because the universities were few with low student enrolments. The story however, changed a few years later with the increase in the number of staff and students. Take for example, the recurrent allocations for the University of Benin for 1978/79, which was about N9 million, and compare it with the 1982/83 allocations, which was about N22.3 million, one would be struck by the apparent large increase in the allocation. It should be noted that these allocations fell short of the minimum requirements. The details of the allocations for the 1978/79-1982/83 sessions are as follows:

Table 4. Allocations to University of Benin, 1978/79 session

\begin{tabular}{llllllll}
\hline Year & $\begin{array}{l}\text { No. of } \\
\text { students }\end{array}$ & $\begin{array}{l}\text { No. of } \\
\text { senior } \\
\text { staff }\end{array}$ & $\begin{array}{l}\text { No. of } \\
\text { juniorstaff }\end{array}$ & $\begin{array}{l}\text { Amount } \\
\text { required }\end{array}$ & $\begin{array}{l}\text { Amount } \\
\text { approved }\end{array}$ & Plus/minus & $\begin{array}{l}\text { Percentage } \\
\text { in drop }\end{array}$ \\
\hline $1978 / 79$ & 2522 & 559 & 1,756 & $14,019,425$ & $9,979,000$ & $4,040,425$ & 28.8 \\
$1979 / 80$ & 3839 & 685 & 2,093 & $17,098,749$ & $11,330,404$ & $5,768,345$ & 33.7 \\
$1980 / 81$ & 5694 & 771 & 2,329 & $24,680,231$ & $20,995,404$ & $3,684,827$ & 14.9 \\
$1981 / 82$ & 6489 & 934 & 2,750 & $30,548,091$ & $22,932,000$ & $7,616,091$ & 24.9 \\
$1982 / 83$ & 7005 & 1,756 & 3,919 & $50,508,930$ & $22,854,000$ & $27,654,930$ & 54.8 \\
\hline
\end{tabular}

Source: Extracted from Recurrent Issues in Nigerian Education (Baikie, 2002)

In table 4, the apparent increase in the allocations for running the University was less than what was required to break even. Furthermore, we should not lose sight of other areas where universities were involved in funding, e.g., provision of housing, water and electricity bills, and other municipal services. This is not an isolated case.

No wonder some university administrators declared that measures to promote higher education and improve the quality of university education to meet the challenges of a constantly changing environment are often constrained by under-funding and inadequate resources (Akinkugbe, 2001; Nwaka, 2000; Ajani, 1999). The expansion of universities in Nigeria without necessary funds has brought about dearth of other resources and facilities. Unavailable and run-down physical infrastructure, inadequate laboratories and ill-equipped libraries are contributory factors to the decline in the university education system. 
This finding was supported by a vice-chancellor who commented that one intractable problem facing Nigerian universities today is the problem of finance. He went further to say:

We find ourselves running establishment (university) with less than we would require to breakeven. This problem is likely to persist for sometime to come particularly as the signals we are seeing now indicate that price of crude oil per barrel may be reduced, and coupled with massive oil theft in the country, the finances of the nation would be affected, and in effect that of the university.

This situation calls for sober reflection.

\subsection{Leadership}

Nigeria is endowed with good quality leadership materials and these are not in short supply in its university system. But because of interests that are more related to personal desires which are reinforced by group and ethnic allegiances. Nigerian universities are quite often deprived of quality leadership. The administration of a university is, more than any other institution in the country, unique, and its success depends on the qualities and personalities of the leader. But when people in leadership position subject themselves to the canker worms of parochialism, nepotism and ethnic chauvinism, then the boat of the university will be rocked irretrievably to destruction.

Even at the level of local elections, where issues and ideas should play a dominant role in winning over the electorates, people appeal to the baser instincts of man and sometimes issue threats. Surely these are not the stuff that leadership is made of, and intellectual community of a university is not deserving of a leadership be it a dean, provost, vice-chancellor or head of department that is parochial, corrupt, partial and unjust. Such a leadership can only generate lack of confidence, mistrust and schism. Take for example, the failure of the Governing Council of the Ahmadu Bello University, Zaria to appoint a substantive Vice-Chancellor three months after the expiration of the tenure of the former Vice-Chancellor, Professor Shehu Usman Abdullahi. In February, 2009 a process that should have culminated in the appointment of the next substantive Vice-Chancellor for the University by its Governing Council in accordance with the Universities (Miscellaneous Provisions) Act 1993 as amended was regrettably annulled (Chafe, 2009). The reasons for the annulment were not far from parochialism, ethnic chauvinism, and religious bigotry. The University had to wait for over seven months, after having two acting Vice-Chancellors heading the institution for three months each, to get a substantive Vice-Chancellor. The Nigerian university system needs to be constantly reminded as Combs (1969) succinctly states:

The universities, being at the apex of educational system, are expected by tradition and common consent to provide the system with its leadership. In addition, they are intended to be the guardian of truth, the seekers of new truths, and the up setters of old dogmas, the conservators of society's heritage, the molders of its youth and the pathfinders of its future. To accomplish these heavy tasks, the University is allowed a privileged sanctuary.

Any deviation from this rational position can only generate loss of confidence, mistrust, and schism. The atmosphere of university community should be charged more by serious academic and intellectual discourse than by the pursuit of personal indulgences often at the expense of enhancing the quality of academic life in the university.An informant (a vice-chancellor) during the interview said there is no question that Nigerian universities are endowed with leaders who are capable of promoting and upholding the roles ascribed to universities. However, because of interests that are driven by ethnicity and religion, the universities do not enjoy the services of quality leaders.

\subsection{Union Activities}

The series of disruptions, closures and violence that characterized union activities in the first twenty years of university education mainly emanated from involvement of staff and students in national and international politics. Inspired by ideology of decolonalisation; welfarism; and independence; the staff and students sought to protect their privileges and academic freedom while simultaneously opposing neo-colonialism in all its ramifications.

However, the period 1980-2013 is characterized by phenomenal expansion of university education. This expansion, inevitably has posed serious challenges such as inadequate funding and the overstretching of limited facilities and these in turn have generated a series of crises in the system. For example, from Abuja Metro investigations, the nation's university system has lost close to three years to strike in 14 years. It is a total of about 33 months, and 15 days as at today and the count continues until the last day of the present strike (Emewu, 2013).

Because these strikes were not continuous, it unleashed 14 interruptions in 14 years, indicating that no year has 
been spared of Academic Staff Union of Universities (ASUU) strike in the period under review.

Table 5. ASUU strikes, 1999-2013

\begin{tabular}{ll}
\hline Year & No. of months \\
\hline 1999 & 5 months \\
2001 & 3 months \\
2003 & 6 months that stretched into early 2004 \\
2006 & 3 days \\
2007 & 1 week \\
2008 & 1 wonths \\
2009 & 4 months \\
2010 & 5 months, 1week \\
2011 & 3 months that extended into 2012 \\
2013 & Over 3 months \\
\hline Total 33 months, (and) 15 days. \\
\hline
\end{tabular}

Source: Daily Sun at www.sunnewsonline.com

From table 5, it is evident that the ASUU strike is taking much of the little time available to the university system. This must be affecting the stability of the system. Supporting this result, an informant (ASUU activist) said that:

The adverse consequences of poor salaries and other conditions of service of university teachers for the university system are great. One of the most pernicious consequences is that the standard of university education declines. A lecturer's job, if it is to be done properly, is almost a twenty-four hour engagement. A lecturer who has to take time off to do other things to supplement his income cannot give his best the system.

The protests of the academic, non-academic staff and students constitute an internal problem facing the university administration. For example, the long strike of ASUU which commenced on the $1^{\text {st }}$ of July 2013 and was called off on the $17^{\text {th }}$ of December of the same year, disrupted academic activities of public universities for over 5 months.

Nigeria is passing through a period in which there is an unprecedented explosion in the demand for higher education. Europe and North America have passed through a similar period of expansion in university education such as the country is experiencing now. During the 1960s, for example, post-secondary age group in Europe and North America was unusually large due to wartime effects on birth rates. This produced an increase which was larger than the general population increase. The universities were consequently flooded by young men and women in quest for higher education. The total enrolment in institution of higher learning went up three times in Canada and more than doubled in the UK (Baikie, 2002). This increase in enrolment inevitably gave rise to a mass system of education arising purely out of a natural consequence of high demand.

Thus, everywhere in the world, there was rising social demand for higher education. The responses to this challenge came in a variety of forms:

$>$ Great Britain at first expanded the "red brick" universities and later transformed its polytechnics and colleges of education into universities. The process was followed by increased "vocationalisation" of higher education.

$>$ The United States of America responded by expanding its two-year community college system, in addition to encouraging private higher education, for which that country is well-known.

$>$ Most of Western Europe, especially France, Italy, Spain and Portugal carried out reforms which ensured that expansion of higher education went along with greater devolution of responsibilities to decentralized educational authorities (like the "Academies" in France). 
$>$ The countries of South-East Asia expanded their national systems in phases, with heavy reliance on the practice of "corporate partnerships".

$>$ A country like Cuba was able to take the challenge in its stride by building everything into its communist style "command economy" (Obanya, 2004).

South Africa has aligned the technikons and the colleges of education with universities in an attempt to expand access.

\subsection{Employment}

Developmentalist project initially designed for Nigerian universities to produce an elite core with the requisite competence and commitment to spear-head the national development plans and thus plays its hegemonic role in ushering the country into modernity was partially successful at least in the production of an elite core (Abubakar, 2004). Furthermore, the internal situation in the universities was stable because the resources were fairly adequate and the employment climate was dynamic.

However, the guidelines for the Third Nation Development Plan, 1975-80, under the section dealing with university education states that it is increasingly being accepted that only a microscopic proportion of students go to universities without having employment or a vocation as their ultimate goal. There may be a serious "mis-match" between out-turn of higher education system and the needs of the labour market (1975-80 plan document).

There is an apparent wave of the unemployment of employable working force in Nigeria. It is paradoxical that a developing country like Nigeria that is definitely in need of educated manpower should find itself in a position in which it is unable to employ and use available manpower. Two possible reasons may be responsible for this state of affairs. First, there may be a mis-match between the out-turn of the university systems and the needs for labour market and the second reason maybe faulty economic development plan.

As Usman(1979) aptly puts it: "it is not because there are too many students from higher education institutions that there is unemployment but because the economic structure is geared to maintaining a high level of unemployment no matter how many graduates or technological institutes you produce." This seems to agree with the view of Combs (1969) who says that: unemployed engineers, for example, are not necessarily a sign that the educational system has produced too many. For many countries it is more likely a sign that the economy and the government have not yet learned how to use engineers-or agriculturists, or architects, or public health specialists - in the best interest of national development

As a matter of fact it is within this category of professionals that Nigeria has the highest percentage of the self-employed. They are mostly described as consultants. However, when the National Manpower Board was directed in 1986 to conduct a sample survey of the unemployed youth, the result was frightening (some $2,000,000$ unemployed youths or 10\%) and this led to the inauguration of Chukwuma Committee in the same year to devise some strategies to curb mass unemployment (Anyebe, 1998). The unemployment rate was 12.5\% in $1999 ; 18.95 \%$ in $2000 ; 13.6 \%$ in $200 ; 12.6 \%$ in $2002 ; 11.2 \%$ in 2003 ; and the $11 \%$ in 2004 (National Planning Commission). The trend, even though, is on the decline, does not show any appreciable prospect for improvement. In fact, the unemployment situation in the country has since grown worse. Unemployment is known to be a discourager of the pursuit of education and this situation worsens social inequalities with the hardest hit being young persons from poor homes.

Complementing this finding, one informant (a director at NUC) commented that the numbers here are swelling by the day. That they remain unemployed after graduating from universities is a source of frustration for them and families. It de-motivates students who are still in school it is capable of causing a variety of social disruptions.

Today, the university system is contending with very many problematic issues which take too much of the little time available at the expense of promoting excellence in the academic programmes of the institutions. These include inadequate teaching and learning facilities; very poor academic preparation of the entrant to the university; dearth of senior academics in the system; ethnicity; the effect of unionism on the stability of the system; examination malpractices; sex abuse; decline in staff training programmes; religious bigotry; politicisation of academic leadership in departments and faculties; issues related to the appointment of vice-chancellors; financial squeeze; and cultism and secret societies. All these issues have been allowed to develop into complexities which are really destabilizing the internal tranquility of the University system. Unfortunately, the resolution of these issues is nowhere in sight and they have remained permanent features in the calendar of activity of universities. 
Professor Pai Obanya, former National Coordinator of the Universal Basic Education in Nigeria, described the country's performance in education as the poorest even by African standards. Professor Obanya disclosed that Nigeria occupies $136^{\text {th }}$ position on global human development index (HDI) out of 162 countries covered by UNDP survey. He went further to say that Nigeria falls below less-endowed countries like Equatorial Guinea, Swaziland, Lesotho, Kenya, Comoro Island, Togo, Madagascar, and Cape Verde. In Africa, Nigeria is $18^{\text {th }}$ out of the 42 countries surveyed (Obanya, 2004). This is a serious indictment of Nigerian educational system. This unenviable status may not be unconnected with the series of crises that have bedeviled the educational system.

From 1980, not only has the number of universities increased exponentially but the traditional notion of such institutions as the engine-houses of state enterprise has also changed. In the context of an evolving market-oriented, competitive and private-sector driven economy, co-operate capitalism and globalization, university education is expected to produce high quality manpower that is versatile enough to acquire competitive positions as well as generate its own employment.

What is perhaps the most important point here is that the demands of the world of work are rapidly changing as current developments indicate that what the future would need most is the "knowledge worker, with flexible and adaptable skills". Besides, universities should serve as power houses and think tanks for the continuous advancement of knowledge, the generation of innovative ideas, the development of the minds of the young and the old and continuous engagement in issues concerning the survival of humanity. Any person who has passed through a university would certainly acquire skills, knowledge, and techniques that could be related to job requirement in specific fields of socio-economic endeavour. But it is also important that the institution passes through him. That is the only way in which he could graduate with the tangibles (e.g., certificates which could be ephemeral) together with the intangibles (life-long and life-wide learning skills, an analytical and creative mind, intrapersonal and interpersonal skills) that are more enduring (Obanya, 2004).

This means that a university should not simply feed the factories and the employers of labour. It should instead undertake that task as part of the more all-embracing one of serving the advancement of the entire society by applying its critical and creative arsenals to generating ideas, creating innovative mental and physical tools and training the creative minds needed for the continuous regeneration of society (Anyebe, 2009). The role of university education in the development and growth of a nation is, therefore, critical, self-evident and inescapable.

\section{Conclusion and Recommendations}

One inescapable conclusion from the findings of this paper is that the expansion in Nigerian university system is characterized by a mixed bag of limited success and continuing challenges. Thus, any attempt to reposition the Nigerian university system must include systematic and planned development of the sector. This is the real area of attention and would involve a number of specific activities, one of which would be an effective evaluation of the current state of university education, including an assessment of the country's capacity to bear its current university education burden. Overstretching of facilities as a result of rapid explosion in student enrolment is a major crisis in Nigerian universities. The situation can be seen from several dimensions:

$>$ Nigeria cannot meet the demand by secondary school leavers for university education.

$>$ Some programmes (mainly in the Humanities) are over-subscribed, while several others (particularly the natural sciences and technology) are under-subscribed.

$>$ The universities are bursting at the seams, while non-university tertiary institutions are not attracting a sufficiently large number of students.

The question then, is whether to retain the existing three-tier system of university education. South Africa has already taken a hard decision of aligning the technikons and the colleges of education with the universities. This development deserves very close monitoring, as the view that non-university tertiary institutions are needed for the "production of middle-level manpower" no longer seems to have the currency it had in the 1960s.

Nigerian university system needs to be planned and the following areas are in need of actions:

$>$ Internal management processes and structures that eliminate waste, promote and reward innovations. This will involve instilling an inquiring, innovative and entrepreneurial frame of mind in students and staff.

$>$ Curriculum reforms that promote the inculcation of the generic skills (communication, inter-personal skills, adaptability, IT-fluency, creativity and lifelong learning skills so valued in today's knowledge economy), while de-emphasizing narrow and premature specialization. This will involve regularly evaluating and continuously improving and renewing university programmes, practices, procedures, and systems. 
$>$ Aligning teaching, research and service functions with the needs of the immediate society-being practically involved in thematic and problem-oriented societal/human activities and generating/disseminating knowledge from these to enrich the world pool of knowledge.

$>$ Nigerian universities would have to acquire the major tools of internationalization-ICT, which must become a "management, learning, and research tool". With appropriately developed ICT capacity, our universities would be reducing the time and space that have separated them for too long from the world epicentres of internationalization.

Nigerian university system should also develop and sustain the financial capacity to support its academic objective by:

$>$ Reorganising and refocusing existing sources of revenue, e.g., consultancy;

$>$ Exploring new sources of revenue, e.g., endownment, organized fund raising, and virile alumni;

$>$ Exploiting the economic value of assets including intellectual property;

$>$ Utilizing partnerships and establishing linkages and collaborations wherever academically possible; and

$>$ Using resources effectively and efficiently.

Finally, Nigerian university system should be run on a stable path by ensuring that:

$>$ Persons appointed to leadership positions in the governance and management of the university system respect fundamental academic nature, goals and aspirations of the system;

$>$ Peace is nurtured and advanced in the university system so that we can have a good student graduation rate and in record time; and

$>$ Appreciation and understanding for diversity is cultivated actively, differing perspectives arising from diverse backgrounds and cultures enrich academic debate and institutional life, give rise to new questions, deepen scholarly inquiry, and build tolerance.

Intellectual activity takes place most effectively when given undivided attention and when academics are able to work in a stable environment. Consequently, one of the most important tasks of the university management is to establish and maintain such an environment.

\section{References}

Abubakar, T. (2005). The Challenges and Prospects of Global or Holistic Students' Management in Nigeria Higher Institutions in the $21^{\text {st }}$ Century, being a lead paper presented at a workshop on Collaborative Approach to Students Management in Nigerian Higher Institutions: Challenges, Strategies and Prospects. Organized by the Higher Education Management Prospect (HEMP) ABU, Zaria and supported by the MacArthur Foundation held in the Institute of Development Research (IDR), Ahmadu Bello University, Zaria $6^{\text {th }}-7^{\text {th }}$ December P1.

Ajani, B. G. (1999). On Educational Problems of Third World. Education, 20(2), 30-38.

Akinkugbe, Y. (2001). Higher Education in Nigeria in Perspective. Proceedings of the $12^{\text {th }}$ General Assembly of the Social Science Academy of Nigeria (SSAN), July 3-7, 12-20.

Anyebe, A. A. (1998). Education and Manpower development in Nigeria. Journal of Problem Solving in Education, 1(1), 10.

Anyebe, A. A. (2009). Towards a Development Oriented Tertiary Education: A Nigerian Perspective. Nuhu Bamalli Managerial Focus, 1(1).

Ayo, J. E. (1988). Development Planning in Nigeria (p. 183). Ibadan: University Press Ltd.

Baikie, A. (2002). Recurrent Issues in Nigerian Education (selected and edited by G. S. Tseja, pp. 269, 271, 274-275). Zaria: Tamaza Publishing Company Ltd.

Beeby, C. E. (1968). The Quality of Education in Developing Countries (p. 9). Cambridge: Harvard University Press.

Chafe, K. S. (2009). The Case for Immediate Dissolution of Ahmadu Bello University's Governing Council and the Imperative for Reconstituting a new Governing Council to handle the appointment of Vice-Chancellor. A position paper written to Honourable Minister of Education and copied to all Professors in the University.

Combs, P. H. (1969). The World Educational Crisis: A Systems Analysis (pp. 17, 18, 89, 125). Oxford: OUP. 
Emewu, I. (2013, October 30). ASUU's N1.58tr war. Daily Sun, 25. Retrieved from http://www.sunnewsonline.com

Federal Government of Nigeria. (1970). NUC Annual Report.

Federal Government of Nigeria. (1989). National Policy on Education (Revised edition). Lagos: NERDC Press.

Federal Government of Nigeria. (2002). National Policy on Education (Revised edition). Lagos: NERDC Press.

Federal Government of Nigeria. National Plan Document, 1981-85.

Federal Ministry of Education. (1981). National Policy on Education (p. 5).

Joint Admissions and Matriculation Board. (2009). Retrieved from http://www.jambng.com/app_ume.php

National Planning Commission. (2004). National Economic Development and Empowerment Strategies (NEEDS) (p. 44).

Nwaka, G. I. (2000). Higher Education, Social Sciences and National Development in Nigeria. Newsletter of the Social Science Academy of Nigeria (SSAN), 3(1), 25-33.

Obanya, P. K. I. (2004). Educating for the Knowledge Economy (pp. 23-24, 142-143, 180). Ibadan: Masuro Publishers.

Usman, Y. B. (1979). For the Liberation of Nigeria (p. 221). London: Beacon Books Ltd.

\section{Copyrights}

Copyright for this article is retained by the author(s), with first publication rights granted to the journal.

This is an open-access article distributed under the terms and conditions of the Creative Commons Attribution license (http://creativecommons.org/licenses/by/3.0/). 